\title{
Preliminary investigation into the effects of earplugs on sound transmission in the equine ear
}

\author{
Paul D. MacFarlane, Martina Mosing and John Burford \\ Philip Leverhulme Equine Hospital, University of Liverpool, Leahurst Campus, Neston, UK
}

\begin{abstract}
Summary
Earplugs are occasionally used to reduce horses responsiveness to noise but there performance has not been evaluated. A modified 'microphone in real ear' technique was used to quantitatively assess the effects of several earplugs on sound transmission in the external ear of equine cadavers. Significant variations in the performance of the earplugs tested were identified. These results may affect the selection of earplugs for clinical use and should inform the design of future investigations into the clinical utility of earplugs in horses
\end{abstract}

Keywords: Anesthesia, earplug, sound, transmission, RMSA, reduction

\section{Pilotstudie über den Effekł von Ohrstöpseln auf die Schallübertragung im Gehörgang von Pferden}

Ohrstöpsel werden bei Pferden verwendet um Umgebungslärm zu reduzieren und dadurch das Pferd zu beruhigen oder ruhig zu halten. Die Schallreduktion der am Markt erhältlichen Ohrstöpsel wurde bisher noch nicht wissenschaftlich evaluiert. In dieser Studie wurde eine modifizierte "Mikrophon in echtem Ohr" Methode verwendet um die Abschwächung der Geräuschübertragung durch kommerziell verfügbare Ohrstöpsel zu messen. Es wurden dafür 6 Pferdekadaver verwendet, die in gleicher Weise in einer gepolsterten Aufwachbox gelagert wurden. Die Dimensionen der Pinna wurden gemessen und aufgezeichnet. Ein Mikrophon wurde in den äußeren Gehörgang eingebracht und Lautsprecher wurden 1.5 Meter von der Nasenspitze entfernt aufgestellt Danach wurde eine definierte Tonabfolge über die Lautsprecher abgespielt und mit dem Mikrophone aufgezeichnet (Basiswert). In weiterer Folge wurden 5 verschiedene kommerziell erwerbbare Ohrstöpsel und ein selbstgemachter Wattestöpsel in randomisierter Folge in den äußeren Ohrkanal distal des Mikrophons eingebracht und die Tonfolge mit jedem Ohrstöpsel dreimal abgespielt und aufgezeichnet. Ein neverlicher Basiswert wurde zwischen jeder Messung aufgezeichnet. Die Schallreduktion (minimale, maximale und mittlere "Root Mean Square" Amplitude = RMSA) von jedem einzelnen Produkt sowie die Differenz in den Basiswerten zwischen den Kadavern wurde mittels Kruskal-Wallis Test mit folgendem post-hoc Test auf Signifikanz überprüft. Signifikante Unterschiede zwischen den 5 Produkten und dem Wattestöpsel wurden in der Reduktion des Schalls gefunden. Nur ein einziger kommerziell verfügbarer Ohrstöpsel (Finntrack 12704) zeigte eine bessere Reduktion der RMSA Werte als die selbstgemachten Wattestöpsel. Ein signifikanter Unterschied wurde im Ausgangswert zwischen den Kadavern gefunden. Kein signifikanter Unterschied wurde zwischen den Basiswerten innerhalb eines Kadavers gefunden. Die Schallreduktion der einzelnen Ohrstöpsel zwischen Kadavern zeigte keinen signifikanten Unterschied. Diese Pilotstudie zeigt, dass ein großer Unterschied in der Schallreduktion zwischen kommerziell verfügbaren Ohrstöpseln besteht. Dies kann die klinische Wahl beeinflussen und eine wichtige Rolle bei zukünftigen Studien spielen in denen eine Schallreduktion eine wichtige Rolle spielt.

Schlüsselwörter: Anästhesie, Ohrstöpsel, Schallübertragung, RMSA Reduktion

\section{Introduction}

Earplugs for horses are commercially available and are used during transport, clipping, showing and racing. The use of earplugs has been advocated during recovery from anaesthesia (Muir and Hubbell 2009). The actual effectiveness of earplug use in horses has not been objectively assessed, either in terms of their effect on sound transmission to the inner ear or the responsiveness of horses to sound. International standards exist for the evaluation of ear protectors in man (British Standard Institute 2002). One of the techniques utilised is the 'Microphone In Real Ear' (MIRE) technique where a small microphone is placed in the horizontal canal of subjects and the effect of ear protectors on the amount of sound transmitted to the microphone is measured.

Sounds can usually be characterized using two parameters, frequency and volume. The sound frequency is measured in oscillations per second $(\mathrm{Hz})$. The auditory range of horses i.e. the range of frequencies which they can perceive, is in the order of $55 \mathrm{~Hz}$ to $33.5 \mathrm{kHz}$, with there region of maximum sensitivity being 1-16kHz (Heffner and Heffner 1983).

The sound volume at any instant is measured as a pressure and is reported in Pascals. Because sound waves oscillate about a zero point the mean pressure over a complete waveform is zero, irrespective of the amplitude (loudness) of the sound. To give a useful measure of sound pressure over time the waveform is squared, converting the negative component to positive, and then a mean value calculated. The square root of this mean value is then calculated and the positive component of the result reported. This is known as Root Mean Squared Amplitude (RMSA). The range of sound pressures, which can be perceived, is very great. For convenience sound pressure levels are often reported in decibels which is the negative base 10 logarithm of the ratio between the measured sound pressure and a reference value - often the lowest sound pressure audible to humans. In man the relationship between sound pressure and perceived volume (loudness) is 
extremely complex (Stevens 1971). An increase in sound pressure of $10 \mathrm{~dB}$, which represents a hundred fold increase, may only be perceived as a doubling of volume.

In order to select earplugs for clinical trials it is necessary to evaluate the physical performance of available earplugs. This pilot study attempts to evaluate the effect of six earplugs on sound attenuation in the equine ear using a MIRE technique in cadavers.

\section{Materials and methods}

Six fresh horse cadavers free from head and neck abnormalities were used in this study. Cadavers were placed in left lateral recumbencey in a padded anaesthesia recovery box. Ear dimensions were measured for each cadaver. Dimensions measured were the long axis of the external ear opening $(L)$, maximum pinnae width (W) and diameter of the ear canal at the level of the ventral pole of the long axis of the ear's external opening (D). Measurements were made using a rigid ruler.

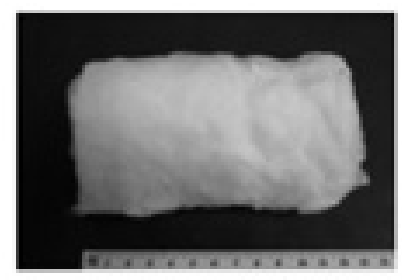

Cotton Wool

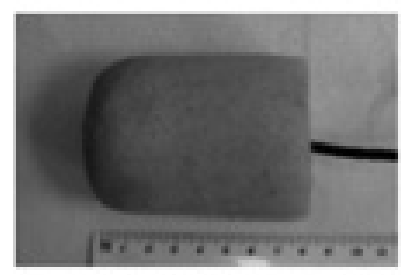

Walsh 1379

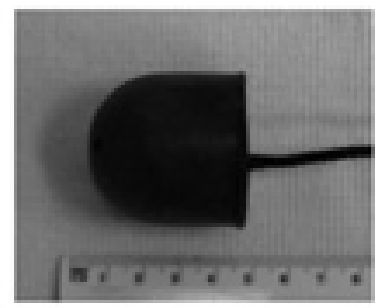

Walsh 1380

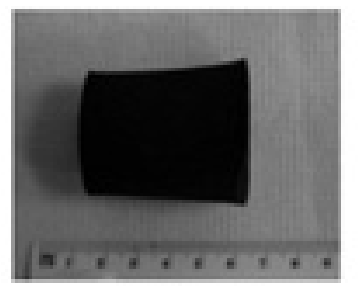

Cashel XL

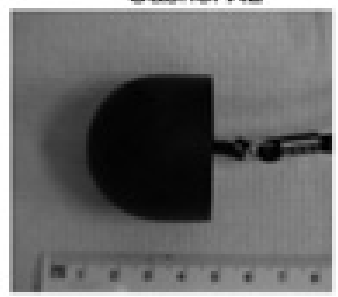

Protecto P-53

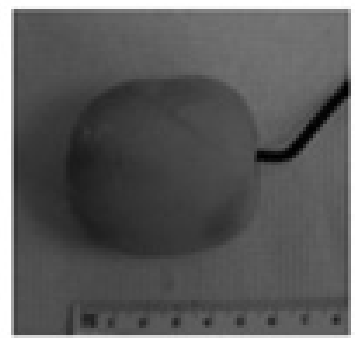

Finntack 12704
Fig. 1 Photographs of earplugs used in the study.

Fotos der verwendeten Ohrstöpsel

Earplugs tested were the Cashel $\mathrm{XL}^{1}(\mathrm{CL})$, Walsh $1379^{2}$ (W9), Walsh $1380^{2}$ (W0), Protecto P $53^{3}(\mathrm{P} 3)$, Finntack $12704^{4}$ (F4), and an improvised cotton wool earplug comprising $10 \times 20 \mathrm{~cm}$ of a single layer of cotton wool ${ }^{5}(\mathrm{CW})$. A sound sample was generated using a software package 6 . The sample comprised 14 bursts of sound; separated from each other by 0.5 seconds of silence. Frequencies in the sound sample were $0.1,0.5,1,2,3,4,5,6,7,8,9,10,11$, and $12 \mathrm{kHz}$. The amplitude was the same for each frequency. The frequencies selected for testing were chosen based on the reported auditory range of horses and the performance criteria of the various electronic components employed (Heffner and Heffner 1983).

Speakers ${ }^{7}$, were positioned one meter apart and $1.5 \mathrm{~m}$ from the cadaver's nose (Fig 2) and connected to a portable media player $^{8}$. The volume settings of the speakers and media player were identical for each cadaver. A micropho$\mathrm{ne}^{9}$, was positioned in the narrow portion of the external ear canal, at the junction between the cartilaginous and osseous regions, (Sargent et al. 2006) and connected to a recording device ${ }^{10}$. The positioning of the microphone was

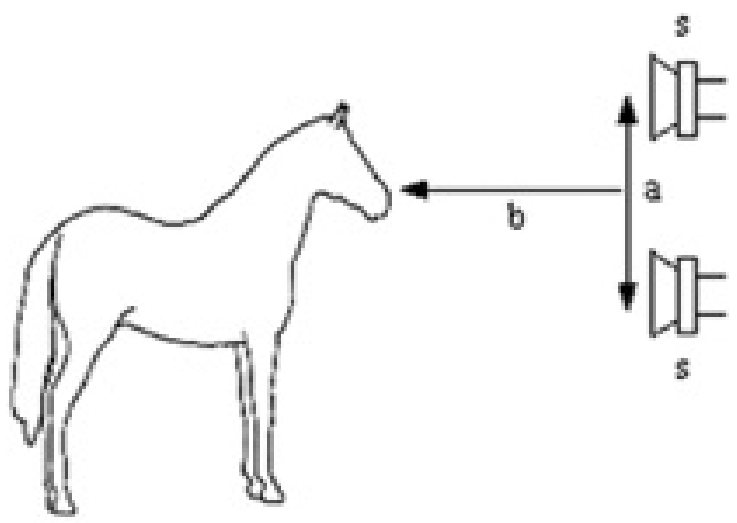

Fig. 2 Position of the cadaver in the recovery box relative to the sound reproduction equipment. ( $s$ ) represents a speaker, ( a ) is the distance between the two speakers $(1 \mathrm{~m})$, and, $(\mathrm{b})$ is the distance from the cadavers nose to the speakers $(1.5 \mathrm{~m})$.

Graphik der Positionierung des Pferdekadavers in der Aufwachbox im Verhältnis zu den Lautsprechern. (s) Lautsprecher, (a) Distanz zwischen den beiden Lautsprechern $(1 \mathrm{~m})$ und (b) der Nase des Pferdes und der Lautsprecher (1.5m)

selected in order to minimise variations in microphone position. The osseous section of the external ear canal is a narrow tube with an approximate diameter of $9 \mathrm{~mm}$ and length of $25 \mathrm{~mm}$ (Sargent et al. 2006). The microphone was selected based on the dimensions of this part of the ear so as to ensure a snug fit.

The sound sample was played and the signal from the microphone recorded. This comprised the baseline sound signal. An earplug was then placed in the ear and the sound sample was played again and the signal from the microphone recorded. The earplug was then removed and the position of the microphone checked by palpation. Each earplug was tested three times in each cadaver. The improvised earplug was always tested last as there was a concern that the cotton wool could fragment in the ear, affecting the performance of other earplugs. If during any test extraneous noise was evident to the experimenter then the test was repeated.

Signals were analysed for minimum, mean and maximum RMSA for the whole sound sample. The difference between each variable measured before and after earplug insertion was calculated (reduction in sound transmission). The earplugs were compared for reduction in sound transmission for minimum, mean and maximum RMSA using Kruskal-Wallis 
analysis. Post-hoc comparisons were performed by calculating a $\mathrm{K}$ statistic for each pair of earplugs and then, comparing this to a standard table (Langley 1968). The baseline sound recordings were compared by earplug and cadaver using the same tests. Significance was defined as $\mathrm{P}<0.05$.

\section{Results}

Visual examination of the recordings showed that sound amplitudes generated at the upper end of the frequency range was less than at lower frequencies (Fig 3 and 4).

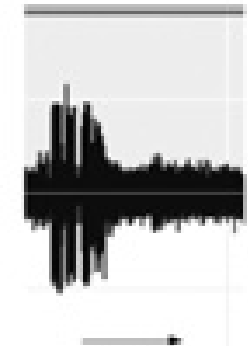

$\frac{\text { Time }}{\text { Baseline recording }}$

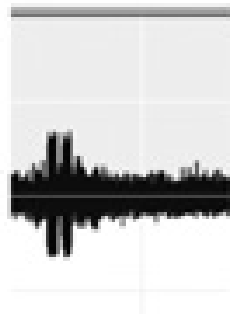

Time

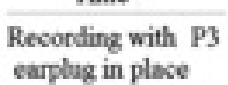

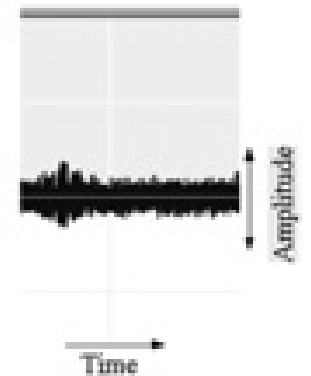

Recooding with $\mathrm{F} 4$ earplag in place
Fig. 3 Visual representation of recordings made with no earplug in place (Baseline) and with the P3 and F4 earplugs in place. The lower sound frequencies are to the left of the recording.

Beispiele der Aufzeichnungen an einem Pferdekadaver mit der Tonaufnahme ohne Ohrstöpsel (Baseline recording) und mit den plazierten Ohrstöpseln P3 (Recording with P3 earplug in place) und F4 (Recording with F4 earplug in place)
The results for reduction in minimum, mean and maximum RMSA for each earplug are summarised (Table 1). Due to the small sample size results are presented as Median (inter-quartile range). There were significant differences between earplugs for reduction in maximum $(P<0.001)$, mean $(P=0.001)$, and minimum $(P=0.031)$ RMSA. For each sound parameter the F4 earplug caused the greatest reduction in sound transmission $(\mathrm{P}<0.05)$. Earplug $\mathrm{CW}$ reduced sound transmission more than the W0, CL, P3 and W9 for all sound parameters $(\mathrm{P}<0.05)$.

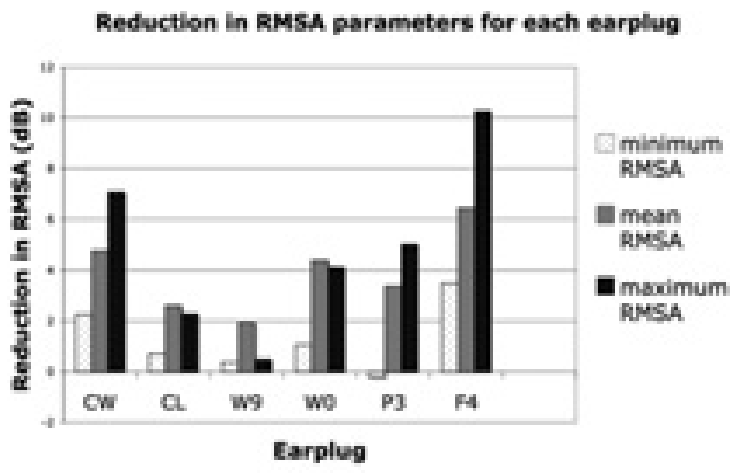

Fig. 4 Bars represent the reduction in minimum, mean and maximum RMSA when the earplugs are in position. i.e. the greater the height of the bar the greater the reduction in sound transmission.

Die Balken representieren die Abschwächung des minimalen, mittleren und maximalen RMSA mit positionierten Ohrstöpseln d.h. je höhre der Balken umso höher die Reduktion der Schallübertragung

Table 1 Median reduction in sound transmission for each earplug compared to baseline recordings. Data shown as median, (Inter-quartile range). The suffix after results indicates the earplugs, which cause significantly less reduction in sound transmission than that to which the result pertains $(\mathrm{P}<0.05)$.

Medianwerte der Abschwächung der Schallübertragung nach Plazierung der Ohrstöpsel im Gehörgang verglichen zu den Basismessungen ohne Ohrstöpsel. Die Daten sind als Medianwert (Interquartilsabstand) angegeben. Die Zusatzkennzeichen hinter den Ergebnissen für die verschiedenen Ohrstöpsel bezeichnen signifikante Unterschiede in der Schallabschwächung zwischen den Ohrstöpseln

\begin{tabular}{|c|c|c|c|}
\hline Earplug & Decrease in minimum RMSA $(\mathrm{dB})$ & Decrease in mean RMSA (dB) & Decrease in maximum RMSA (dB) \\
\hline F4 & $3.5(1.1)^{\mathrm{CW}, \mathrm{W} 0, \mathrm{P} 3, \mathrm{Cl}, \mathrm{Wg}}$ & $6.5(1.5)^{\mathrm{CW}, W 0, \mathrm{P} 3, \mathrm{Cl}, \mathrm{Wg}}$ & $10.25(3.9)^{\mathrm{CW}, \mathrm{WO}, \mathrm{P} 3, \mathrm{Cl}, \mathrm{Wg}}$ \\
\hline $\mathrm{CW}$ & $2.3(1.4)^{\mathrm{W} 0, \mathrm{P} 3, \mathrm{Cl}, \mathrm{Wg}}$ & $4.8(1.7)^{\mathrm{wo}, \mathrm{P} 3, \mathrm{Cl}, \mathrm{Wg}}$ & $7.1(2.0)^{\mathrm{W} 0, \mathrm{P} 3, \mathrm{Cl}, \mathrm{wg}}$ \\
\hline WO & $1.1(0.7)^{\mathrm{P} 3, \mathrm{Cl}, \mathrm{Wg}}$ & $4.4(1.7)^{\mathrm{P3}, \mathrm{Cl}, \mathrm{Wg}}$ & $4.1(4.3)^{\mathrm{Cl}, \mathrm{Wg}}$ \\
\hline P3 & $-0.2(1.4)$ & $3.4(0.9)^{\text {w9 }}$ & $5.0(1.7)^{\mathrm{w} 9, \mathrm{Cl}}$ \\
\hline $\mathrm{Cl}$ & $0.7(1.0)^{\mathrm{P3}, \mathrm{W} 9}$ & $2.6(2.1)^{\text {w9 }}$ & $2.3(2.6)^{\mathrm{wg}}$ \\
\hline W9 & $0.4(0.6)$ & $1.9(0.6)$ & $0.5(0.5)$ \\
\hline
\end{tabular}

Table 2 Baseline sound transmission for each cadaver, and ear dimensions. Baseline results are presented as Median (Inter Quartile Range), ear dimensions are Long axis $\times$ Width $x$ Depth.

Basiswerte der Schallübertragung für jeden Kadaver und Messwerte für die Ohrdimensionen. Basiswerte werden als Medianwerte (Interquartilsabstände) und Ohrdimensionen werden als Längsachse (Long axis) x Breite (Width) x Tiefe (Depth) angegeben.

\begin{tabular}{ccccc}
\hline Cadaver & $\begin{array}{c}\text { Baseline minimum } \\
\text { RMSA (dB) }\end{array}$ & $\begin{array}{c}\text { Baseline average } \\
\text { RMSA (dB) }\end{array}$ & $\begin{array}{c}\text { Baseline maximum } \\
\text { RMSA (dB) }\end{array}$ & Ear Dimensions (cm) \\
\hline 1 & $-25.3(0.5)$ & $-18.6(0.3)$ & $-11.0(0.3)$ & $15 \times 6 \times 5.5$ \\
2 & $-22.0(0.6)$ & $-17.2(0.5)$ & $-11.2(0.3)$ & $14 \times 5.5 \times 4$ \\
3 & $-26.1(2.1)$ & $-17.9(0.5)$ & $-10.5(0.1)$ & $15.5 \times 6 \times 5$ \\
4 & $-23.4(0.3)$ & $-18(0.1)$ & $-11.2(0.1)$ & $15 \times 5.6 \times 4.8$ \\
5 & $-25.1(0.2)$ & $-19.1(0.2)$ & $-10.8(0.0)$ & $18.2 \times 6 \times 4.8$ \\
6 & $-25.9(1.7)$ & $-18.1(0.3)$ & $-10.7(0.2)$ & $16 \times 5.5 \times 5$
\end{tabular}


There were small but statistically significant differences between the baseline recordings (Table 2 and fig 4) made in each cadaver for all RMSA parameters $(P<0.005)$. The baseline sound recordings did not differ significantly between earplugs for any sound parameter $(P>0.5)$. The reduction in sound transmission caused by earplugs for each RMSA parameter did not differ significantly between horses $(P>0.15)$. The measured dimensions of the horse's ears are shown in table 2 .

\section{Discussion}

The results of this study show that there are significant differences between commercially available earplugs in terms of their ability to reduce sound transmission in the equine ear. The best performing earplug in this study (F4) reduced maximum RMSA by $10.25 \mathrm{~dB}$. Due to the logarithmic nature of the Decibel scale this represents a large change in sound pressure. However, at least in man, the relationship between perceived volume and actual sound pressure is non-linear and a decrease of $10 \mathrm{~dB}$ approximates to a halving of perceived volume in most circumstances. The degree to which sound level must be reduced to prevent horses reacting to noise has not been evaluated. This means that the effect of these earplugs in a clinical situation cannot be predicted. However it is obvious that the earplug, which reduces sound transmission to the greatest extent is most likely to be effective.

The design of the earplugs tested differed markedly in terms of shape and materials used. The F4 earplug used 'memory foam'; the W0 and P7 were of similar shape and used 'closed cell' PVC foam, the W9 used 'open cell foam' and the $C L$ 'closed cell' polythene foam. In theoretical models it has been shown that both the design and materials used in the construction of ear defenders is likely to impact upon their performance (Paurobally and Pan 2000). However, this study was not designed to compare the materials or design of earplugs, but rather the effectiveness of the two combined.

The improvised cotton wool earplug reduced sound transmission to a greater extent than all but one of the commercial products. The amount of cotton wool selected for its construction was arbitrary as was the grade of cotton wool used. Changing either of these two attributes could affect the performance of a cotton wool earplug (Paurobally and Pan 2000). One potential clinical disadvantage of the CW earplug is that unlike most of the commercial designs it does not feature a lanyard, and so removal of the earplug may be more difficult. It is also possible that a cotton wool earplug could fragment during use or on removal, leaving debris in the ear.

There were small but statistically significant differences in baseline sound recordings between cadavers. A number of factors may have contributed to this: the level of background environmental noise may have changed from day to day; the exact orientation of the ear may have varied; the shape of the ear varied in each cadaver; and the precise positioning of the cadaver within the induction box may have differed slightly. A flaw in the experimental design was the positioning of the nose $1.5 \mathrm{~m}$ from the microphone rather than the ears - this means that for horses with larger heads the ears would have been further from the speakers than in horses with smaller heads. In man tests of ear protectors are conducted in special rooms, which are designed to limit interference from external noise and provide predictable sound transmission (British Standard Institute 2002). A similar facility large enough to accommodate an equine cadaver was not available, and this may have contributed to the differences between horses. It is unlikely that these differences affected the outcome of this study as we evaluated the reduction in sound transmission associated with the use earplugs in each individual cadaver rather than the absolute sound levels. In effect therefore each horse acted as its own control. However depending on study design some of these sources of variation could potentially affect the results of future clinical trials of earplugs and should be taken into account during the design phase.

The dimensions of the horses ears differed and in man external ear canal dimensions have been shown to affect the performance of earplugs (Abel et al. 1990). The number of horses in the study was small and a larger study might identify differences between the effectiveness of earplugs in horses with differing ear anatomy.

The standard sound was designed so that the amplitude of sound would be equal for each frequency tested. However when the recordings were scrutinised it was apparent that the sound amplitudes generated at the upper end of the frequency range were less than at lower frequencies If the earplugs did not alter sound transmission equally at different frequencies then the results in this study could be skewed towards earplugs which performed better at lower frequencies.

The standard sound did not cover the complete auditory range of the horse, with sounds between 12 and $16 \mathrm{kHz}$ not being included (Hefner and Hefner 1983). These frequencies were outside the range of performance stated by the manufacturers for the various electronic components used. Again this could bias our results towards earplugs that perform better at lower frequencies.

This study only examines the transmission of sound in the external ear canal. Other pathways exist for sound to reach the cochlea - notably the bone conduction pathway (Ravicz and Melcher 2001). To the author's knowledge the relative contributions of the different sound conduction pathways have not been evaluated and it may be that bone conduction plays an important role in horses, which would limit the clinical value of earplugs. In this study the horses heads lay on the floor and so conduction of sound could have occurred from the speaker, through the floor to the head. This could have increased the relative contribution of bone conduction.

Future studies should: attempt to evaluate the performance of earplugs across a fuller range of frequencies; evaluate the effect of earplugs on horses ability to detect sounds and; assess the effect of using earplugs on horses behaviour in noisy environments.

This pilot study showed that there are significant differences in the effect of commercially available earplugs on sound trans- 
mission in the external equine ear. It also identified several study design factors of significance to further work in this area. Only one of the commercial products outperformed an improvised cotton wool earplug. When selecting earplugs for clinical use or future trials the large differences between the available earplugs should be considered.

\section{Manufacturers addresses}

1 Cashel Company, 115 Klein Road, Chehalis, Washington 98532, USA

2 Walsh Harness \& Saddlery, 2745 North Calhoun Road, Brookfield, WI 53005 USA

3 Protecto Horse Equipment, P.O.Box 215, Clawson, Michi gan 48017, USA

4 Oy Finn-Tack Ltd. Keskikankaantie 29-31, 14860 Hollola, Finland

5 Robinson Healthcare Ltd. Worksop, Nottinghamshire, S81 9LB, UK

6 Amadeus Pro, HairerSoft, 3, Washington Sq Vlg, Apt 131, New York, NY 10012, USA

7 JBL Duet, Harman Consumer Group International, Hünderstraße 1, 74080 Heibronn, Germany

8 iPod Shuffle M9724LL/A, Apple Sales International, Holyhill Industrial Estate, Holyhill, Cork, Republic of Ireland

9 Olympus ME-15, Olympus UK Ltd, Vision House, 19 Colonial Way, Watford, Hertfordshire, WD24 4JL, UK

10 Olympus WS-311M, Olympus UK Ltd, Vision House, 19 Colonial Way, Watford, Hertfordshire, WD24 4JL, UK

\section{References}

Abel S. M., Rockley T., Goldfarb D. and Hawke M. (1990) Outer ear canal shape and its relation to the effectiveness of sound attenuating earplugs. J. Otolaryngol. 19, 91-95

British Standard Institute BS EN 13819-2:2002 BSI, London

Heffner R. S. and Heffner H. E. (1983) Hearing in Large Mammals: Horses (Equus caballus) and Cattle (Bos taurus). Behav. Neurosci. 97, 299-309

Langley R. (1968) Practical statistics simply explained, 1st edn.. Pan, London pp 212-221

Muir W. M. ande Hubbell J. A. E. (2009) Equine Anaesthesia, 2nd edn., Saunders Elsevier, London, pp 384-395

Paurobally M. R. and Pan J. (2000) The mechanisms of passive ear defenders. Appl. Accoust. 60, 293-311

Ravicz M. E. and Melcher J. R. (2001) Isolating the auditory system from acoustic noise during functional magnetic resonance imaging: Examination of noise conduction through the ear canal, head, and body. J. Acoust. Soc. Am. 109, 216-231

Sargent S..J., Frank L..A., Buchanan B..R., Donnell R.L. and Morandi F. (2006) Otoscopic, cytological, and microbiological examination of the equine external ear canal. Vet. Dermatol. 17, 175-181

Stevens S. S. (1971) perceived levels of noise by mark VII and Decibels (E). J. Acoust. Soc. Am. 51, 575-601

Dr. Martina Mosing, DipECVAA, MRCVA

Philip Leverhulme Equine Hospital

Leahurst campus

Chester High Road

Neston, CH64 7TE

UK

mmosing@liverpool.ac.uk 